\title{
IMPLEMENTATION OF INTERNAL-RESONANCE LASER SPECROSCOPY IN THE EXAMINATION OF THE ELECTROPHYSICAL CHARACTERISTICS OF BLOOD ELEMENTS
}

\author{
Teodora Petrova ${ }^{1}$, Simeon Simeonov ${ }^{2}$, Denis Solovev ${ }^{3}$ \\ ${ }^{1}$ Assist. Prof. Ph.D., Georgi Benkovski Air Force Academy, Dolna Mitropoliya, Bulgaria \\ teodorapetrova33@abv.bg \\ ${ }^{2}$ Ph.D, University Hospital Kaneff - Rousse, Bulgaria, sansiood@abv.bg \\ ${ }^{3}$ Associate Professor, Ph.D., Far Eastern Federal University (FEFU), Vladivostok, Russian \\ Federation, solovev.db@dvfu.ru
}

\begin{abstract}
The suggested model for assessment of the refractive index and the size of blood constituents might turn out to be more informative and precise than the existing models, which utilize non-resonance methods. This approach provides for the discovery of a correlation between the electrophysical parameters of blood cells and their biological properties. Evaluation of the incident and scattered monochromatic laser radiation is given as a key of understanding optical characteristics of bio-matter.
\end{abstract}

Keywords: medicine, biology, lasers, mathematical modeling.

\section{INTRODUCTION}

Nowadays, laser technology is actively used for solving broad class of problems in various fields of science and technology, from physics and chemistry to biology and medicine. Laser sources are employed for diagnosis, therapy, surgical interventions, etc.

In order to solve these problems, first, one should pick the most informative indicators, which characterize the vital functions of an organism. Such indicators are the results from the analysis of peripheral blood since it travels through all organs and tissues in the body and carries enough information about its condition. The complex study of the characteristics of scattering and absorption of light allow for a quick and contactless discovery of physiological and morphological changes in cells caused by temperature, chemical effects and others.

As it is known, blood consists of the following microstructures (Boren, Hafman, 1986; Petrova, 2019b, pp. 346-353; Kulikov, Radin, 2002; Terziev, Petkova - Georgieva, 2019f, pp. 515-524): leukocytes, erythrocytes and thrombocytes. Examination of the optical properties of these biological objects allows for solving a number of problems about the diagnosis of different pathological processes, which occur within organism. Before developing a mathematical model, which describes the interaction between laser radiation and the complex-structured blood cells, it is necessary to look at their geometric structure.

Let begin with the cells which concentration is the highest in blood - the erythrocytes. Erythrocytes are cells, which have a specific shape - flattened biconcave disk. There is no nucleus in the cell and the main part of erythrocyte cytoplasm consists of a peculiar protein - hemoglobin. Normally, $70-80 \%$ of the erythrocytes have a biconcave shape while the rest $20-30 \%$ can have different shapes (i.e. spherical, oval, shrunken and spiky, etc.). Erythrocyte shape could be impaired by various diseases, for example, sickle-shaped erythrocytes are typical of the sickle cell anemia (Balandin, Shurina, 2000; Petrova, Petrov, 2018, pp.213- 
228; Stoev, Zaharieva, Mutkov, 2019d, pp 454-457; Atanasov, 2019).

Leukocytes are a big class of blood cells, which includes a few kinds, namely granulocytes and agranulocytes - monocytes and lymphocytes. Granulocytes or polymorphonuclear leukocytes are a subgroup of the white blood cells and are characterized with the presence of a widely segmented nucleus and the presence of specific granules in the cytoplasm, which can be observed under optical microscope after being stained. The granules are large lysosomes and peroxisomes or altered organelles. Granulocytes are the most numerous group of leukocytes and their quantity comprises about $50-80 \%$ of all white blood cells. Their size varies in between 9 to $13 \mu \mathrm{m}$. Typically, in human blood circulation there are about $2-9 \times 10^{9} / L$ granulocytes. Granulocytes are formed in the bone marrow from a common ancestor cell (hemocytoblast). Granulocytes include: neutrophils, eosinophils and basophils. The neutrophil has a circular shape and a diameter of $12-16 \mu \mathrm{m}$. It's nucleus is concave with smooth outline and are kidney-shaped. A neutrophil with rod-like shaped nucleus is a young cell, while with segmented nucleus is a mature cell. In blood, most of the neutrophils have segmented nucleus (up to 95\%) and the ones having a rod-like nucleus are $5 \%$.

Eosinophils (acidophils), with a size of $12-15 \mu \mathrm{m}$, similarly to neutrophils, have a circular shape and rod-like or segmented nucleus. The granules, located in cell cytoplasm, are relatively big and with equal size and form. They contain chemical mediators, which, once released by a process called degranulation following the activation of the eosinophil, are toxic to both parasites and host tissues.

Basophils are the fewest type of granulocytes. Cell diameter is between 9-14 $\mu m$ (largest of all granulocytes) and have a circular shape and nucleus with two lobes. Their cytoplasm is oxyphilic and contains large granules with different shapes.

The monocyte is a big cell with a diameter of $14-22 \mu \mathrm{m}$. The ratio nucleus-cytoplasm is almost $1: 1$. The nucleus has various forms - oval, kidney-like or segmented. As stated before, the monocyte is an agranulocyte. They possess all the properties of neutrophils but has considerable phagocytic capacity and longer lifespan.

Lymphocytes are circular cells with various shapes and sizes and have a big oval nucleus. They are located mainly in the lymph nodes, spleen, thymus, bone marrow, tonsils, lymphoid aggregations in the alimentary canal, respiratory and urogenital tract. There are two major types of lymphocytes: T cells and B cells. The T cells take part in cell immunity while the B cells produce antibodies, which carry out the humoral immunity. Both types of lymphocytes are produced by hematopoietic stem cells in the bone marrow and their differentiation into immunocompetent T- or B-lymphocytes happens in the thymus (T-cells) or in the bone marrow (B-cells).

Thrombocytes (platelets) are small circular or oval disks. Their size is $1-4 \mu m$ in diameter and $0,5-0,75 \mu m$ in thickness. Although thrombocytes do not possess nucleus and cannot reproduce, they are functionally active cells and play a crucial role in blood coagulation.

An electrodynamical model of the interaction between laser radiation and blood cells is made in order to predict their electrophysical properties. An effective approach which allows to examine the processes in complex biosystems is the use of optical internal-resonance methods.

It is presumed that in the neighborhood of the $Z$ axis in the region $\Omega$ of a linear resonator is placed a cuvette with a sample from biotissue which models the blood elements (Fig. 1).

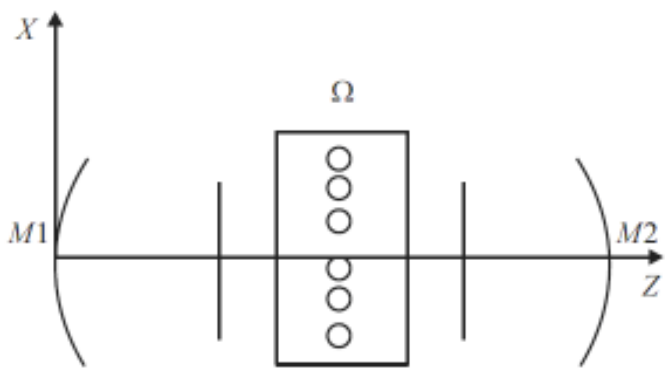

Fig. 1. Linear resonator and sample from biotissue, simulation of blood cells

It is also assumed that the particles, which model the formal components of blood, more precisely - the 
erythrocytes, have a spherical form, which can be viewed as a first approximation; the rest of the blood elements can be described as spheres with nonconcentric inclusion. The size of the particles is larger than the wavelength of the wave falling on the field, i.e. $k a^{j}>1$, where $a^{j}$ is the radius of particle $j$ and $k=2 \pi / \lambda$ ( $\lambda$ is the wavelength) is the wave number. Let suppose that in this case, over a group of particles with radii $a^{j}$ and with a complex refractive index $N^{j}=n^{(0) j}+i \chi^{j}$, where $j$ is the number of the particle, falls a linearly polarized electromagnetic wave. Here, $n$ and $\chi$ (generally denoted by $k$ ) are nonnegative. The real part of the complex refractive index, $n$, is the ratio between the speed of light and the phase velocity in a medium $-n=c / v$, whereas the imaginary part, $\chi$, is the attenuation of the wave as it propagates through a medium. The direction of the falling wave is arbitrary. A collections of particles is examined in threedimensional coordinate system with its origin positioned in the center of a particle with number $j_{0}$. The radius vector of any other $j$-particle is $\mathbf{r}_{j_{0}, j}$.

Let us consider a quasi-monochromatic wave falling on an uncharged particle which changes in time as $e^{\omega t}$. The electric and magnetic fields of the wave can be presented in the following forms:

(1) $\quad \vec{E}=\vec{E}_{0} e^{i(\vec{k} \cdot \vec{r}-\omega t)} \quad \vec{H}=\vec{H}_{0} e^{i(\vec{k} \cdot \vec{r}-\omega t)}$

The fields must comply with the Maxwell equations for free space:

$$
\begin{aligned}
& \operatorname{div} \vec{E}=0, \\
& \operatorname{div} \vec{H}=0, \\
& \operatorname{rot} \vec{E}=-\frac{\partial}{\partial t}(\mu \vec{H})=-\mu \vec{H}_{0} e^{i(\vec{k} \cdot \vec{r}-\omega t)}(-i \omega)=i \omega \mu \vec{H}, \\
& \operatorname{rot} \vec{H}=\varepsilon \frac{\partial}{\partial t}(\vec{E})=\varepsilon \vec{E}_{0} e^{i(\vec{k} \cdot \vec{r}-\omega t)}(-i \omega)=-i \omega \varepsilon \vec{E},
\end{aligned}
$$

where $\varepsilon$ (permittivity) and $\mu$ (permeability) are continuous at all points. The curl of (4) and (5) is

$$
\begin{aligned}
& \operatorname{rot} \operatorname{rot} \vec{E}=i \omega \mu \operatorname{rot} \vec{H}=\omega^{2} \varepsilon \mu \vec{E}, \\
& \operatorname{rot} \operatorname{rot} \vec{H}=-i \omega \mu \operatorname{rot} \vec{E}=\omega^{2} \varepsilon \mu \vec{H},
\end{aligned}
$$

and by utilizing the vector identity

$$
\text { rot } \operatorname{rot} \vec{u}=\operatorname{grad} \operatorname{div} \vec{u}-\Delta \vec{u}
$$

we obtain

$$
\Delta \vec{E}+k^{2} \vec{E}=0 \quad \Delta \vec{H}+k^{2} \vec{H}=0,
$$

where $k^{2}=\omega^{2} \varepsilon \mu$. Consequently, $\mathbf{E}$ and $\mathbf{H}$ satisfy the vector wave equation (note that $\mathbf{E}$ and $\vec{E}$ can be used interchangeably and the same rule apply for $\mathbf{H}$ and $\vec{H}$ ). It is necessary to find a solution for the natural fluctuations of the optical resonator in which cavity there is a group of scattering particles with complex structure.

\section{SCATTERING BY A COLLECTION OF SPHERICAL BODIES}

The electromagnetic field which falls on the surface of the ${ }^{j}$-particle consists of two parts - the initial falling field and the field scattered by a group of particles which are positioned in the neighboring area. Therefore, we can write the following equations:

$$
\mathbf{E}_{i}(j)=\mathbf{E}_{0}(j)+\sum_{\substack{l \\ l \neq j}} \mathbf{E}_{s}(l, j),
$$




$$
\mathbf{H}_{i}(j)=\mathbf{H}_{0}(j)+\sum_{\substack{l \\ l \neq j}} \mathbf{H}_{s}(l, j)
$$

where $\mathbf{E}_{s}(l, j)$ and $\mathbf{H}_{s}(l, j)$ are the scattered fields by the $j$-particle, while $\mathbf{E}_{i}(j)$-the incident electric field, $\mathbf{E}_{0}(j)$-the initial electric field, and $\mathbf{E}_{s}(l, j)$ - the scattered electric field, are defined in (Boren, Hafman,1986).

A system of linear algebraic equations for finding the coefficients $a_{m n}^{j}$ and $b_{m n}^{j}$, including the possibility for multiple scattering by the $j$-particle with nonconcentric inclusion, is similar to the method observed is (Kulikov 2012; Petrova, Petrov, 2019c, pp. 29-40) and has the following form:

$$
\begin{aligned}
& a_{m n}^{j}=\left[p_{m n}^{j, j}-\sum_{l \neq j}^{L} \sum_{v=1}^{\infty} \sum_{\mu=-v}^{v}\left[a_{\mu v}^{l} A_{m n}^{\mu v}(l, j)+b_{\mu v}^{l} B_{m n}^{\mu v}(l, j)\right]+\right. \\
&+\left[q_{m n}^{j, j}-\sum_{l \neq j}^{L} \sum_{v=1}^{\infty} \sum_{\mu=-v}^{v}\left[a_{\mu v}^{l} B_{m n}^{\mu v}(l, j)+b_{\mu v}^{l} A_{m n}^{\mu v}(l, j)\right]\right] \\
& b_{m n}^{j}= {\left[q_{m n}^{j, j}-\sum_{l \neq j}^{L} \sum_{v=1}^{\infty} \sum_{\mu=-v}^{v}\left[a_{\mu \nu}^{l} A_{m n}^{\mu v}(l, j)+b_{\mu v}^{l} B_{m n}^{\mu \nu}(l, j)\right]\right]+} \\
&+ {\left[p_{m n}^{j, j}-\sum_{l \neq j}^{L} \sum_{v=1}^{\infty} \sum_{\mu=-v}^{v}\left[a_{\mu v}^{l} B_{m n}^{\mu v}(l, j)+b_{\mu v}^{l} A_{m n}^{\mu v}(l, j)\right]\right] } \\
& n=1,2,3,4,5, \ldots . ., \quad m=1,2,3,4,5, \ldots n .
\end{aligned}
$$

System (10) can be rewritten in a form of a matrix:

$$
\left(\begin{array}{l}
a^{j} \\
b^{j}
\end{array}\right)=T_{1}^{j}\left[\left(\begin{array}{l}
p^{j, j} \\
q^{j, j}
\end{array}\right)+\sum_{l \neq j}\left(\begin{array}{ll}
A(l, j) & B(l, j) \\
B(l, j) & A(l, j)
\end{array}\right)\left(\begin{array}{l}
a^{j} \\
b^{j}
\end{array}\right)\right]+T_{2}^{j}\left[\left(\begin{array}{l}
p^{j, j} \\
q^{j, j}
\end{array}\right)+\sum_{l \neq j}\left(\begin{array}{ll}
A(l, j) & B(l, j) \\
B(l, j) & A(l, j)
\end{array}\right)\left(\begin{array}{l}
a^{j} \\
b^{j}
\end{array}\right)\right],
$$

or

$$
\begin{gathered}
\left(\begin{array}{l}
a^{j} \\
b^{j}
\end{array}\right)=T_{12}^{j}\left[\left(\begin{array}{l}
p^{j, j} \\
q^{j, j}
\end{array}\right)+\sum_{l \neq j}\left(\begin{array}{ll}
A(l, j) & B(l, j) \\
B(l, j) & A(l, j)
\end{array}\right)\left(\begin{array}{l}
a^{j} \\
b^{j}
\end{array}\right)\right], \\
T_{12}^{j}=T_{1}^{j}+T_{2}^{j}, \quad T_{1}^{j}=\left(\begin{array}{cc}
a_{n_{1 p}}^{j} & 0 \\
0 & b_{n_{1 q}}^{j}
\end{array}\right), \quad T_{2}^{j}=\left(\begin{array}{cc}
0 & a_{n_{1 q}}^{j} \\
b_{n_{1 p}}^{j} & 0
\end{array}\right),
\end{gathered}
$$

where $A(l, j), B(l, j)$ are translation coefficients which are defined in (Balandin, Shurina, 2000; Kulikov, Radin, 2002; Atanasov, 2019) and $p^{j, j}$ and $q^{j, j}$ can be found in (Terziev, Petkova - Georgieva, 2019g, pp. 525-533; Stoev, Zaharieva, Borodzhieva, 2019e, pp 458-461).

System (12) should be solved with the help of the reduction method leaving in the algebraic system only a finite number of equations and finite numbers of unknowns (Kulikov, Radin, 2002; Petrova, Petrov, 2018, 213-228) by utilizing the algorithm of bi-conjugated gradients (Ninov, Atanasov, 2019a, pp. 101-108; Terziev, Bogdanova, Kanev, Georgiev, Simeonov, 2019h). We can write the expressions of the scattered electric and magnetic fields in the main coordinate system: 


$$
\begin{aligned}
& \mathbf{E}_{s}=\sum_{n=1}^{\infty} \sum_{m=-n}^{n} i E_{m n}\left[a_{m n} \mathbf{N}_{m n}^{3}+b_{m n} \mathbf{M}_{m m}^{3}\right], \\
& \mathbf{H}_{s}=\frac{k}{\omega \mu} \sum_{n=1}^{\infty} \sum_{m=-n}^{n} E_{m n}\left[b_{m n} \mathbf{N}_{m n}^{3}+a_{m n} \mathbf{M}_{n m}^{3}\right],
\end{aligned}
$$

where $\mathbf{N}$ and $\mathbf{M}$ are the vector spherical harmonics and $m$ and $n$ are separation constants which are determined by subsidiary conditions that the generating function of $\mathbf{N}$ and $\mathbf{M}$ must satisfy. We can also define:

$$
\begin{aligned}
\mathbf{E}_{m n} & =\left|\mathbf{E}_{0}\right| i^{n}[2 n+1] \frac{(n-m) !}{(n+m) !}, \\
a_{m n} & =\sum_{l=1}^{L} \sum_{v=1}^{\infty} \sum_{\mu=-v}^{v}\left[a_{\mu v}^{l} A_{m n}^{\mu v}\left(l, j_{0}\right)+b_{\mu v}^{l} B_{m n}^{\mu v}\left(l, j_{0}\right)\right], \\
b_{m n} & =\sum_{l=1}^{L} \sum_{v=1}^{\infty} \sum_{\mu=-v}^{v}\left[a_{\mu v}^{l} B_{m n}^{\mu v}\left(l, j_{0}\right)+b_{\mu v}^{l} A_{m n}^{\mu v}\left(l, j_{0}\right)\right] .
\end{aligned}
$$

The system for finding $a_{m n}^{j}$ and $b_{m n}^{j}$ can be simplified if we observe a part of field, scattered by particles, which is limited to a small angle around the $Z$ axis. The equations for the scattered field in this region are:

$$
\begin{aligned}
& E_{s \theta} \sim E_{0} \frac{e^{i k r}}{-i k r} \sum_{n=1}^{\infty} \sum_{m=-n}^{n}(2 n+1) \frac{(n-m) !}{(n+m) !} \times\left[a_{m n} \tau_{m n}+b_{m n} \pi_{m n}\right] e^{i m \phi} \\
& E_{s \phi} \sim E_{0} \frac{e^{i k r}}{-i k r} \sum_{n=1}^{\infty} \sum_{m=-n}^{n}(2 n+1) \frac{(n-m) !}{(n+m) !} \times\left[a_{m n} \pi_{m n}+b_{m n} \tau_{m n}\right] e^{i m \phi}
\end{aligned}
$$

Where

$$
\tau_{m n}=\frac{\partial}{\partial \theta} P_{n}^{m}(\cos \theta), \quad \pi_{m n}=\frac{m}{\sin \theta} P_{n}^{m}(\cos \theta)
$$

The symbol $(\sim)$ means that equations (17) and (18) which are consequence of (12) for $k r>>1$ should be taken into account as asymptotic. If we examine the scattering at great distances from the $j$-particle, than the electric vectors of the scattered field would be parallel to the electric vector of the incident field and in the distant zone only the $\theta$ component of the vector would be distinct from zero. We observe only this part of the field, which has not escaped the resonator. Equations (17) and (18) would simplify to:

$$
\begin{gathered}
E_{s \theta} \sim E_{0} \frac{e^{i k r}}{-i k r} \sum_{n=1}^{\infty} \sum_{m=-n}^{n} \frac{(2 n+1)}{n(n+1)}\left[a_{m n} \tau_{n}+b_{m n} \pi_{n}\right], \\
E_{s \phi} \sim E_{0} \frac{e^{i k r}}{-i k r} \sum_{n=1}^{\infty} \sum_{m=-n}^{n} \frac{(2 n+1)}{n(n+1)}\left[a_{m n} \pi_{n}+b_{m n} \tau_{n}\right],
\end{gathered}
$$

Where

$$
\tau_{n}=\frac{\partial}{\partial \theta} P_{n}(\cos \theta), \quad \pi_{n}=\frac{1}{\sin \theta} P_{n}(\cos \theta)
$$

In an analog way, one can derive the expressions for the magnetic field $H$. Now, we need the elements of the scattering matrix, which expresses the correlation between Stokes parameters of the incident and scattered fields (Balandin, Shurina, 2000):

$$
L_{s}=S L_{i}
$$


where $L_{i}$ is Stokes vector of the incident field, $L_{s}$ - Stokes vector of the scattered field, $S-$ the $4 \times 4$ scattering matrix which elements can be expressed with the elements of a $2 \times 2$ matrix which gives the relation between the perpendicular components of the electric vector of the scattered wave $\left(E_{\| s}, E_{\perp s}\right)$ and the incident wave $\left(E_{\| i}, E_{\perp i}\right)$ :

$$
\left(\begin{array}{c}
E_{\| s} \\
E_{\perp s}
\end{array}\right)=\left(\begin{array}{c}
E_{s \theta} \\
-E_{s \phi}
\end{array}\right)=\frac{e^{-i k r-i k z}}{-i k r}\left(\begin{array}{cc}
S_{2} & S_{3} \\
S_{4} & S_{1}
\end{array}\right)\left(\begin{array}{c}
E_{\| i} \\
E_{\perp i}
\end{array}\right) \text {. }
$$

To describe the scattering of the field in fort- and backward direction in a neighborhood resulting from a small change in the angle of wave direction, it is sufficient to limit ourselves to a diagonal representation of Muller's matrix $S$ :

$$
S=\left(\begin{array}{cccc}
S_{11} & 0 & 0 & 0 \\
0 & S_{22} & 0 & 0 \\
0 & 0 & S_{33} & 0 \\
0 & 0 & 0 & S_{44}
\end{array}\right),
$$

where

$$
S_{11}=\frac{1}{2}\left[\left|S_{2}\right|^{2}+\left|S_{1}\right|^{2}\right]=S_{22}, \quad S_{33}=\frac{1}{2}\left[S_{1} S_{2}^{*}+S_{2} S_{1}^{*}\right]=S_{44}
$$

Here with upper index $(*)$ is denoted the complex conjugate of the corresponding variable and the equations of the scattering amplitudes $S_{1}$ and $S_{2}$ for the wave, which has passed through, $(\theta=0)$ and the reflected wave $(\theta=\pi)$ have the following form:

$$
\begin{gathered}
S_{2}(0)=S_{1}(0)=\frac{1}{2} \sum_{n=1}^{\infty} \sum_{m=-n}^{n}(2 n+1)\left[a_{m n}+b_{m n}\right], \\
S_{2}(\pi)=-S_{1}(\pi)=\frac{1}{2} \sum_{n=1}^{\infty} \sum_{m=-n}^{n}(2 n+1)(-1)^{n}\left[a_{m n}-b_{m n}\right] .
\end{gathered}
$$

Expressions (19) will be used to calculate the frequencies of the genuine deviations of the optical cavity in which there is a number of spherical particles (Govedarski et al. 2013; Genadiev et al. 2015; Kirilova Doneva et al. 2015a; Sopotenski, Petrova, Chervenyakov, 2011; Kirilova-Doneva, Kamusheva, Petrova, Sopotenski, 2016; Tsonkova, 2018b; Tsonkova, 2014).

\section{CONCLUSION}

The model can be accomplished in a form of complex programs, which allow in an automatic regime for changes in the results from measuring the real and imaginary parts of the refractive index and the sizes of particles in a particular setting. This approach provides for observing the presence of a correlation between the electrophysical parameters of blood cells and their biological properties. In the meantime, the optical properties of blood cells is a fundamental knowledge for broadening the informational value when rigorous blood analysis is to be performed since they gives significant characteristic of cells (Terziev, PetkovaGeorgieva, 2019i-o).

The suggested model for estimation of the refractive index and the size of blood ingredients in combination with internal resonance experiments can appear to be more informative and precise than the existing methods, which utilize nonresonant models.

\section{REFERENCE LIST}

Balandin M.Yu., Shurina E.P. (2000). Metoday resheniya SLAU bolyshoy razmernosti. Novosibirsk, 2000 (Баландин М.Ю., Шурина Э.П. (2000) Методы решения СЛАУ большой размерности. Новосибирск, 2000). 
Boren K., Hafman D. (1986). Pogloshtenie i rasseyanie sveta malaymi chastitsami/Per. S angl. Z.I. Feyzulina, A.G. Vinogradova, L.A. Persyana. M., 1986 (Борен К., Хафман Д. Поглощение и рассеяние света малыми частицами/Пер. С англ. З.И. Фейзулина, А.Г. Виноградова, Л.А. Персяна. М., 1986).

Kulikov K.G., Radin A.M. (2002). Opt. i spektr. 2002. T. 92. № 2. S. 228-236 (Куликов К.Г., Радин А.М. Опт. и спектр. 2002. Т. 92. № 2. С. 228-236).

Kulikov K.G. (2012). ZHTF. 2012. T. 82. Vayp. 12. S. 24-28 (Куликов К.Г. ЖТФ. 2012. Т. 82. Вып. 12. С. 24-28).

Atanasov, Plamen. (2019) "Variation of the Organisational Reputation in A 4.0 Environment - Fighting for Trust under the Conditions of Communicational Abundance". Postmodernism Problems 9 (2), 248-69.

Ninov, M., Atanasov P. (2019a) Content Analysis as a Way of Identifying Hybrid Threats in the Media Content, International Journal on Information Technologies and Security, No. 3 (vol. 11), 2019, pp. 101-108.

Petrova T., (2019b), Modeling Of Temperature Distribution In Biotissues, Proceedings of SOCIOINT 20196th International Conference on Education, Social Sciences and Humanities, 24-26 June 2019Istanbul, Turkey, pp. 346-353, ISBN 978-605-82433-6-1

Petrova T., Petrov Zh., (2018), Modelling the Distribution of Lasers in Biological Tissues, Int J Bioautomation, 22 (3), 213-228, doi: 10.7546/ijba.2018.22.3.213-228

Petrova T., Petrov Zh., (2019c), Peculiarities in the Distribution of Temperature under the Influence of a Laser Beam in a Multilayered Medium, Int J Bioautomation, 23 (1), 29-40, doi: 10.7546/ijba.2019.23.1.29-40

Stoev I., Zaharieva S., and Mutkov V. (2019d), Evaluation of Gross Errors in Measured Temperature with an Electronic System for Management of Residential Energy Systems, International Scientific Conference 27th Telecommunications Forum, ISBN: 978-1-7281-4789-5, pp 454-457

Stoev I., Zaharieva S., and Borodzhieva A. (2019e), An Approach for Assessment of the Synchronization Between Digital Temperature Sensors, International Scientific Conference 27th Telecommunications Forum, ISBN: 978-1-7281-4789-5, pp 458-461

Terziev, V., Petkova - Georgieva, S. (2019f) The performance measurment system key indicators and the determinants impact on the level of decentralization using as an example a subdivisional unit from the Bulgarian social health and care experience. // Proceedings of SOCIOINT 2019-6th International Conference on Education, Social Sciences and Humanities 24-26 June 2019- Istanbul, Turkey, International Organization Center of Academic Research, Istanbul, Turkey, 2019, pp. 515-524, ISBN: 978-605-82433-6-1 DOI: 10.2139/ssrn.3411542

Terziev, V., Petkova - Georgieva, S. (2019g) A research study of nonlinearity experiencing in the rate of current account deficit to the Bulgarian health and care national product. // Proceedings of SOCIOINT 2019- 6th International Conference on Education, Social Sciences and Humanities 24-26 June 2019Istanbul, Turkey, International Organization Center of Academic Research, Istanbul, Turkey, 2019, pp. 525-533, ISBN: 978-605-82433-6-1. DOI: 10.2139/ssrn.3411558

Terziev, V., Bogdanova, M., Kanev, D., Georgiev, M, Simeonov, S. (2019h) The social assistance system in Bulgaria. // Proceedings of ADVED 2019 - 5th International Conference on Advances in Education and Social Sciences, 21-23 October 2019, International Organization Center of Academic Research, Istanbul, Turkey, 2019, pp. 391-397, ISBN: 978-605-82433-7-8.

Govedarski, V., Kratunkov, P., Petrov, I., Genadiev, S., Zahariev, T., Nachev, G. (2013). Embolizatsii na anomalni sadove pri tumorni formatsii. // Hirurgiya, 69, 2013, №2, s. 44-47; ISSN 0450-2167 45924 (Говедарски, В., Кратунков, П., Петров, И., Генадиев, С., Захариев, Т., Начев, Г. Емболизации на аномални съдове при туморни формации. // Хирургия, 69, 2013, №2, с. 44-47; ISSN 0450-2167 45924).

Genadiev, S., Govedarski, V., Petrov, I., Zahariev, T., Nachev, G. (2015). Hirurgichni metodi za lechenie na varikoznata bolest. // Balgarska gradna, sardechna i sadova hirurgiya, 2015, №1, s. 34-39; ISSN 1313-9339 51956 (Генадиев, С., Говедарски, В., Петров, И., Захариев, Т., Начев, Г. Хирургични методи за лечение на варикозната болест. // Българска гръдна, сърдечна и съдова хирургия, 2015, №1, c. 34-39; ISSN 1313-9339 51956). 
Kirilova - Doneva, M., D. Pashkouleva, V. Kavardzhikov, S. Sopotensky, G. Petrova, N. Gerasimov. (2015a). Evaluation of mechanical alternations of expanded hernia mesh - Series on Biomechanics, vol. 29, No 2-3, 2015.

Sopotenski, S., Petrova, G., Chervenyakov, A. (2011). Achalasia: surgical and social aspects of diagnostics and therapy. Meditsinski Pregled / Medical Review 2011 Vol. 47 No. 1 pp. 19-29.

Kirilova-Doneva, M., Kamusheva, M., Petrova, G., Sopotenski, S. (2016). Comparison of costs for elective versus emergency hernia repair and its reimbursement in Bulgaria, EESJ, 2016, v.2, 9(13), 43-49.

Tsonkova, Eva. (2018b). Nablyudenie varhu efekta na preparata Bimbi apetito pri lechenie na 17g.patsientka s nachalni simptomi na Anorexia Nervosa. Sp. Pediatriya, tom LVIII, 2018, str.46-48, ISSN 0479-7876 (Цонкова, Ева. Наблюдение върху ефекта на препарата Бимби апетито при лечение на 17г.пациентка с начални симптоми на Anorexia Nervosa. Сп. Педиатрия, том LVIII, 2018, стр.4648, ISSN 0479-7876).

Tsonkova, Eva. (2014). Retrospektivno 10-godishno prouchvane varhu babrechno - kamennata bolest sred hospitaliziranite patsienti v Detsko otdelenie na MBAL Ruse AD. // Nauchni trudove na Rusenski universitet 2014, tom 53, seriya 8.3., str.256-259, ISSN 1311-3321 (print), ISSN 2535-1028 (CDROM), ISSN 2603-4123 (on-line) (Цонкова, Ева. Ретроспективно 10-годишно проучване върху бъбречно - каменната болест сред хоспитализираните пациенти в Детско отделение на МБАЛ Русе АД. // Научни трудове на Русенски университет 2014, том 53, серия 8.3., стр.256-259, ISSN 1311-3321 (print), ISSN 2535-1028 (CD-ROM), ISSN 2603-4123 (on-line)).

Terziev, V., Petkova- Georgieva, S. (2019i). The level of decentralization impact on the Bulgarian social health care competitiveness. // Proceedings of ADVED 2019 - 5th International Conference on Advances in Education and Social Sciences, 21-23 October 2019, International Organization Center of Academic Research, Istanbul, Turkey, 2019, pp. 361 - 368, ISBN: 978-605-82433-7-8.

Terziev, V., Petkova- Georgieva, S. (2019j). The Bulgarian health care system practical research on the usefulness of the performance measurement system. // Proceedings of ADVED 2019 - 5th International Conference on Advances in Education and Social Sciences, 21-23 October 2019, International Organization Center of Academic Research, Istanbul, Turkey, 2019, pp. 369 - 375, ISBN: 978-605-82433-7-8.

Terziev, V., Petkova- Georgieva, S. (2019k). The pesticides toxic impact on the human health condition and the ecosystem. // Proceedings of ADVED 2019 - 5th International Conference on Advances in Education and Social Sciences, 21-23 October 2019, International Organization Center of Academic Research, Istanbul, Turkey, 2019, pp. 376 - 382, ISBN: 978-605-82433-7-8.

Terziev, V., Petkova- Georgieva, S. (2019I). Human health problems and the classification of the most toxic pesticides. // Proceedings of ADVED 2019 - 5th International Conference on Advances in Education and Social Sciences, 21-23 October 2019, International Organization Center of Academic Research, Istanbul, Turkey, 2019, pp. 383 - 390, ISBN: 978-605-82433-7-8.

Terziev, V., Petkova- Georgieva, S. (2019m). Organo-phosphonate, organo-halogenated, cyanides and arsenic toxic impact on the human health care condition. // Proceedings of ADVED 2019 - 5th International Conference on Advances in Education and Social Sciences, 21-23 October 2019, International Organization Center of Academic Research, Istanbul, Turkey, 2019, pp. 426 - 431, ISBN: 978-605-82433-7-8.

Terziev, V., Petkova- Georgieva, S. (2019n). Toxic chemical compounds detection for the society social health care prevention. // Proceedings of ADVED 2019 - 5th International Conference on Advances in Education and Social Sciences, 21-23 October 2019, International Organization Center of Academic Research, Istanbul, Turkey, 2019, pp. 432 - 442, ISBN: 978-605-82433-7-8.

Terziev, V., Petkova- Georgieva, S. (2019o). Human health prevention by detection and quantification oftoxic chemical compounds. // Proceedings of ADVED 2019 - 5th International Conference on Advances in Education and Social Sciences, 21-23 October 2019, International Organization Center of Academic Research, Istanbul, Turkey, 2019, pp. 443 - 449, ISBN: 978-605-82433-7-8. 